\title{
Physicochemical Data of Carbonic-Anhydrase-Blended Aqueous Potassium Lysinate Solutions as New Absorbents
}

\author{
Suleman, Humbul; Fosbøl, Philip Loldrup
}

Published in:

Journal of Chemical and Engineering Data

Link to article, DOI:

10.1021/acs.jced.9b00963

Publication date:

2020

Document Version

Publisher's PDF, also known as Version of record

Link back to DTU Orbit

Citation (APA):

Suleman, H., \& Fosbøl, P. L. (2020). Physicochemical Data of Carbonic-Anhydrase-Blended Aqueous

Potassium Lysinate Solutions as New Absorbents. Journal of Chemical and Engineering Data, 65, 2383-2391. https://doi.org/10.1021/acs.jced.9b00963

\section{General rights}

Copyright and moral rights for the publications made accessible in the public portal are retained by the authors and/or other copyright owners and it is a condition of accessing publications that users recognise and abide by the legal requirements associated with these rights.

- Users may download and print one copy of any publication from the public portal for the purpose of private study or research.

- You may not further distribute the material or use it for any profit-making activity or commercial gain

- You may freely distribute the URL identifying the publication in the public portal 


\title{
Physicochemical Data of Carbonic-Anhydrase-Blended Aqueous Potassium Lysinate Solutions as New Absorbents
}

\author{
Humbul Suleman and Philip Loldrup Fosbøl*
}

Cite This: https://dx.doi.org/10.1021/acs.jced.9b00963

Read Online

ABSTRACT: In this study, the physicochemical properties of an enzyme-activated biological solvent for carbon capture were experimentally measured. The solvent consists of an amino acid (L-lysine) mixed with carbonic anhydrase, a composition inspired from human respiration. Densities and viscosities of aqueous blends of carbonic anhydrase enzyme and L-lysine solutions have been measured using an Anton Paar DMA 4100 (capillary type) density meter and a Paar AMV 200 (rolling ball type) viscometer at atmospheric conditions, for a variety of temperatures (303.15$343.15 \mathrm{~K}$ ) and solution concentrations. The results were compared to various conventional solvents used for carbon dioxide capture, which includes monoethanolamine (MEA), $N$-methyldiethanol-
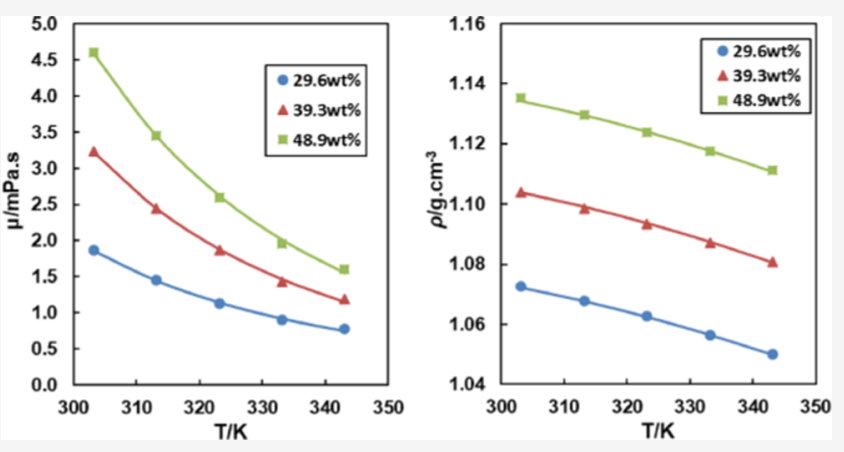
amine (MDEA), and 1-butyl-3-methylimidazolium tetrafluoroborate $\left(\mathrm{BMIMBF}_{4}\right)$. The studied solvent has a slightly higher density than MEA and MDEA but is lower than $\mathrm{BMIMBF}_{4}$. In addition to that, our solvent has a slightly higher viscosity than MEA but lower than that of MDEA. This offers comparable performance in terms of mass transfer rates in the absorber, pumping costs, and heat transfer. The results were modeled by a semiempirical equation. The model can predict densities and viscosities for a range of solvent concentrations of L-lysine and carbonic anhydrase with high accuracy (AAD\% of $0.06 \%$ for density and $2.86 \%$ for viscosity) and can satisfactorily predict density and viscosity values at other parametric conditions.

\section{INTRODUCTION}

Numerous techniques have been investigated for the removal of carbon dioxide from fuel and flue gas streams, like absorption, adsorption, use of membranes, and cryogenic distillation. ${ }^{1}$ These technologies are currently under various phases of research, development, and commercialization, but their widespread use is sometimes debated because of their toxic nature and adverse effects if leaked to the environment. ${ }^{2}$

The use of absorption systems involving chemical solvents is prevalent among the process industries. The solvent choice is attributed to the absence of commercial alternatives and the ease in plant operation. Ammonia, potassium carbonate, monoethanolamine (MEA), diethanolamine (DEA), $N$-methyldiethanolamine (MDEA), 2-amino-methyl-1-propanol $(\mathrm{AMP})$, piperazine $(\mathrm{PZ})$, and their mixtures are common among solvents in absorption systems. ${ }^{3}$ Although these solvents offer good reactive kinetics and capture capacity, they are often corrosive and toxic. This is due to issues with low biodegradability and fugitive emissions. ${ }^{4}$ The degradation of alkanolamines cause fugitive emissions of hazardous byproducts, such as formaldehyde. This threatens to disturb the delicate ecological balance in both on- and off-shore applications. If a carbon capture process could be reengineered, the environmental risks and toxicity from conventional solvents will be alleviated and contribute to an increase in the social and scientific acceptability of carbon capture and storage (CCS).

Amino acids and ionic liquids are advocated as green solvents that can replace the conventional $\mathrm{CO}_{2}$ capture solvents. Being biomimetic, less volatile, environmentally friendly, and stable against thermal degradation (but prone to oxidative degradation, see more information in the Supporting Information), amino acids are more advantageous over conventional chemical solvents. ${ }^{5}$

Amino acids are chemically $\mathrm{CO}_{2}$-inactive and do not absorb carbon dioxide. Their zwitterion behavior is favorably used to make them $\mathrm{CO}_{2}$ active. Amino acids act as both an acid and base in an aqueous medium, which strongly depends on the $\mathrm{pH}$ of the water. Equation 1 below shows the zwitterion behavior of a general amino acid having an R-side chain.

Received: October 12, 2019

Accepted: April 10, 2020 


$$
\begin{aligned}
& \mathrm{NH}_{3}^{+}-\mathrm{R}-\mathrm{COOH} \\
& \text { acidic } \\
& \stackrel{-\mathrm{H}^{+}}{\rightleftarrows} \mathrm{NH}_{3}^{+}-\underset{\text { neutral }}{\mathrm{R}-\mathrm{COO}^{-}} \\
& \stackrel{-\mathrm{H}^{+}}{\rightleftarrows} \mathrm{NH}_{2}-\underset{\text { basic }}{\mathrm{R}-\mathrm{COO}^{-}}
\end{aligned}
$$

In a basic medium, the $\mathrm{NH}_{3}^{+}$ion of an amino acid loses its excessive hydrogen ion to form an amine bond $\left(\mathrm{NH}_{2}\right)$, which is also called the conjugated base form of an amino acid. Mostly, a strong base like potassium hydroxide is used to achieve this conjugate form. ${ }^{6}$ The metal ion present in the base associates itself with the carboxyl group of the amino acid to stabilize it, as shown in eq 2 .

$$
\begin{aligned}
& \mathrm{NH}_{3}^{+}-\mathrm{R}-\mathrm{COO}^{-}+\mathrm{KOH} \\
& \rightleftarrows \mathrm{NH}_{2}-\mathrm{R}-\mathrm{COO}^{-} \mathrm{K}^{+}+\mathrm{H}_{2} \mathrm{O}
\end{aligned}
$$

The amine bond of this alkaline salt of amino acid resembles the amine bond of an alkanolamine, as shown in Figure $1 .^{77}$ The names of these conjugate bases are sometimes referred to as salts, like the potassium salt of L-lysine is called potassium lysinate for brevity.

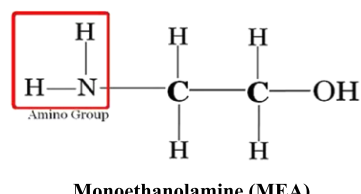

Monoethanolamine (MEA)

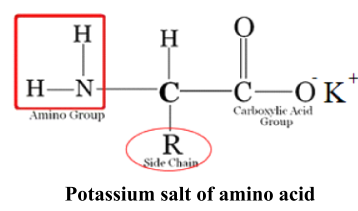

Potassium salt of amino acid
Figure 1. Similarity in the structure of the amine $\left(\mathrm{NH}_{2}\right)$ bond of monoethanolamine, a conventional solvent and a potassium salt of general amino acid with an R-side chain.

The R-side chain of an amino acid consists of a variety of molecules and forms a basis of their classification. The molecules in the R-side chain vary from simple ones like a single hydrogen in glycine to complex cyclic rings in alanine. Of the twenty naturally occurring amino acids, L-lysine, Lhistidine, and L-arginine are the basic amino acids, as they have extra amine/amide bond(s) in their R-side chain. This extra amine bond can absorb additional carbon dioxide, contributing to the enhancement of the carbon dioxide absorption capacity. ${ }^{1414}$ Among the basic amino acids, L-lysine is comparatively better studied. Shen et al. ${ }^{8}$ first studied the physicochemical information of a pure L-lysine system along with its carbon dioxide absorption capacity. Several publications from the same group have studied the solvent's absorption capacity, ${ }^{9-11}$ reaction kinetics, ${ }^{12}$ performance at desorber conditions ${ }^{13}$ and simulation/comparisons with other solvents. ${ }^{14,15}$ Mazinani et al. ${ }^{16}$ have also studied the carbon dioxide solubility of the L-lysine system at low pressure. Suleman et al. ${ }^{17}$ have studied the carbon dioxide absorption capacity of L-lysine at high pressure $(100-4000 \mathrm{kPa})$ and compared its performance to MEA. Investigations about Llysine show that it has good carbon dioxide absorption capacity but nominal kinetic rates. This will require larger absorption columns. The addition of promoter/co-solvents in small amounts to amino acid salts may provide good absorption rates. A recent study by Syalsabila et al. ${ }^{18}$ and Suleman et al. ${ }^{19}$ have studied the equilibrium capacity of piperazine and 2amino-methyl-1-propanol (AMP) as a co-promoter for enhanced absorption with L-lysine at high pressure (100$4000 \mathrm{kPa}$ ). The results show that the addition of piperazine slightly reduces the absorption capacity of L-lysine, whereas the AMP has a positive effect. This indicates that piperazine is not a good option as a kinetic promoter for potassium lysinate solutions.

Our study is inspired from human respiration, where the blood plays an active role in transporting carbon dioxide from the human organs to the human lungs. An enzyme present in the blood, called carbonic anhydrase, facilitates this process. It helps carbon dioxide to dissolve in the aqueous contents of blood by forming a bicarbonate at a high carbon dioxide concentration. The bicarbonate then travels to the lungs, where the reaction is reversed at a low carbon dioxide concentration, releasing its dissolved carbon dioxide into a gaseous form. Both forward and backward reactions are catalyzed by the same enzyme. We have investigated the performance of the said enzyme for a conventional carbon capture process at experimental, ${ }^{20}$ modeling, ${ }^{21}$ and pilot scales $^{22}$ with promising results. We are now extending its application to the biological carbon capture solvent, the potassium salt of L-lysine.

All densities and viscosities were determined at $101.325 \mathrm{kPa}$ $(u=0.3 \mathrm{kPa})$ and for a temperature range of $303.15-343.15 \mathrm{~K}$ $(u=0.1 \mathrm{~K})$ using an Anton Paar DMA 4100 density meter and a Paar AMV 200 viscometer, respectively. The potassium lysinate solutions were prepared at concentrations of 29.6$48.9 \mathrm{wt} \%$, while the carbonic anhydrase concentrations ranged from 0 to $3.4 \mathrm{~g} \cdot \mathrm{L}^{-1}$ of solution. An upper limit of $48.9 \mathrm{wt} \%$ potassium lysinate concentration was selected (based on a recent study ${ }^{19}$ ) to avoid the possibility of precipitate formation upon dissolution of carbon dioxide.

\begin{tabular}{|c|c|c|c|c|c|}
\hline materials & abbreviation & CAS & $\begin{array}{c}\text { purity } \\
\text { (mass fraction) }\end{array}$ & source & analytical method for purity analysis \\
\hline $\begin{array}{l}\text { potassium } \\
\text { hydroxide }\end{array}$ & $\mathrm{KOH}$ & $1310-58-3$ & 0.863 & Merck Denmark & titration curve (acidimetric, $\mathrm{KOH}$ ) \\
\hline $\begin{array}{l}\text { L-lysine } \\
\text { monohydrate }\end{array}$ & Lys & $39665-12-8$ & 0.990 & Merck Denmark & $\begin{array}{l}\text { perchloric acid titration, calculated on an anhydrous substance } \\
\text { basis }\end{array}$ \\
\hline carbonic anhydrase & CA & $9001-03-0$ & 0.990 & $\begin{array}{l}\text { Novozymes Inc. } \\
\text { Denmark }\end{array}$ & Wilbur Andersen unit drop count for Trizma buffer \\
\hline sodium chloride & $\mathrm{NaCl}$ & $7647-14-5$ & 0.995 & Merck Denmark & argentometric titration \\
\hline water & $\mathrm{H}_{2} \mathrm{O}$ & $7732-18-5$ & $\sim 1.000$ & In-house (DTU) & conductivity and resistivity analysis \\
\hline
\end{tabular}

A semiempirical model was developed to correlate the experimental results with excellent accuracy. The model is able to predict densities and viscosities for a range of aqueous blends of potassium lysinate and carbonic anhydrase with high accuracy (an overall error of $2.98 \%$ ). It correlates well with

Table 1. Sample Provenance Table 
Table 2. Reference Density $(\rho)$ and Viscosity $(\mu)$ Values of Pure Water and Aqueous Solutions of Sodium Chloride $\left(w_{1}\right)$ at Different Temperatures $(T)$ and Atmospheric Pressure ${ }^{a, b}$

\begin{tabular}{|c|c|c|c|c|c|c|c|c|c|c|}
\hline \multicolumn{5}{|c|}{ pure water } & \multicolumn{6}{|c|}{ sodium chloride $(1)+$ water $(2)$} \\
\hline \multirow[b]{2}{*}{$T(\mathrm{~K})$} & \multicolumn{2}{|c|}{$\rho\left(\mathrm{g} \cdot \mathrm{cm}^{-3}\right)$} & \multicolumn{2}{|c|}{$\mu(\mathrm{mPa} \cdot \mathrm{s})$} & \multirow[b]{2}{*}{$T(\mathrm{~K})$} & \multirow[b]{2}{*}{$w_{1}$ (mass fr.) } & \multicolumn{2}{|c|}{$\rho\left(\mathrm{g} \cdot \mathrm{cm}^{-3}\right)$} & \multicolumn{2}{|c|}{$\mu(\mathrm{mPa} \cdot \mathrm{s})$} \\
\hline & this study & ref 23 & this study & ref 24 & & & this study & ref 25 & this study & ref 26 \\
\hline 293.15 & 0.9981 & 0.9986 & 0.998 & 1.001 & 293.15 & 0.12 & 1.0863 & 1.0858 & 1.254 & 1.234 \\
\hline 303.15 & 0.9952 & 0.9960 & 0.799 & 0.797 & 293.15 & 0.16 & 1.1172 & 1.1155 & 1.362 & 1.351 \\
\hline 313.15 & 0.9929 & 0.9926 & 0.662 & 0.653 & 293.15 & 0.20 & 1.1465 & 1.1474 & 1.418 & 1.420 \\
\hline 323.15 & 0.9880 & 0.9884 & 0.552 & 0.547 & 325.15 & 0.12 & 1.0562 & 1.0561 & 0.663 & 0.666 \\
\hline 333.15 & 0.9839 & 0.9835 & 0.463 & 0.467 & 325.15 & 0.16 & 1.0941 & 1.0947 & 0.721 & 0.723 \\
\hline 343.15 & 0.9781 & 0.9781 & 0.409 & 0.404 & 325.15 & 0.20 & 1.1258 & 1.1269 & 0.769 & 0.765 \\
\hline 353.15 & 0.9720 & 0.9722 & 0.359 & 0.355 & & & & & & \\
\hline
\end{tabular}

${ }^{a}$ Standard uncertainties are $u(T)=0.1 \mathrm{~K}, u(P)=0.3 \mathrm{kPa}$, and $u\left(w_{1}\right)=0.001$ mass fraction. ${ }^{b}$ Expanded uncertainties are $U_{\mathrm{c}}(\rho)=0.0124 \mathrm{~g} \cdot \mathrm{cm}^{-3}$ and $U_{c}(\mu)=0.023 \mathrm{mPa} \cdot \mathrm{s}(0.95$ level of confidence).

Table 3. Experimental Values of Density $(\rho)$ for [Potassium Lysinate + L-Lysine $]^{a}(1)+$ Water $(2)$ as a Function of the Mass Fraction of Potassium Lysinate $\left(w_{1}\right)$ and Grams of Carbonic Anhydrase Per Kilogram of the Solution $\left(w_{3}\right)$ at Different Temperatures $(T)$ and Pressure $=101.325 \mathrm{kPa}^{b, c}$

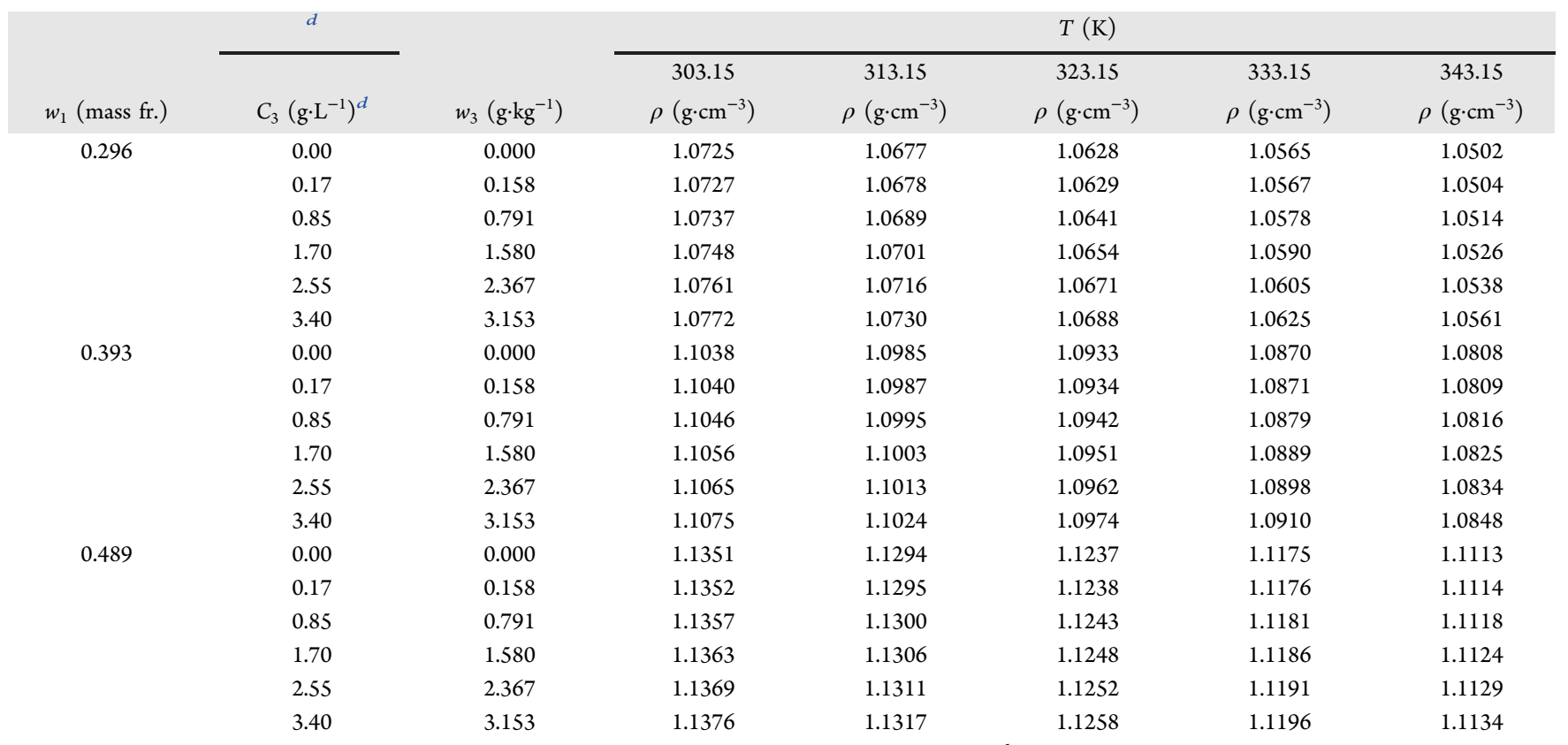

${ }^{a}$ Potassium lysinate formed in this study contains a 0.0065 mass fraction of unreacted L-lysine. ${ }^{b}$ Standard uncertainties are $u(T)=0.1 \mathrm{~K}, u(P)=0.3$ $\mathrm{kPa}, u\left(C_{3}\right)=0.001$ mass fraction, and $u\left(w_{1}\right)=0.001$ mass fraction. ${ }^{c}$ Expanded uncertainty is $U_{\mathrm{c}}(\mu)=0.0163 \mathrm{~g} \cdot \mathrm{cm}^{-3}\left(0.95\right.$ level of confidence). ${ }^{d} C_{3}$ is the concentration of carbonic anhydrase in $1 \mathrm{~L}$ of solution.

other results from the open literature on potassium lysinate solutions without $\mathrm{CA} .^{8}$

For the process development, density and viscosity values are primarily required for mass transfer, column design, and flow calculations.

\section{MATERIALS AND METHODS}

2.1. Chemicals Used in This Study. L-Lysine monohydrate and potassium hydroxide were acquired from Merck Denmark (Copenhagen, Denmark). Novozymes Inc. (Bagsværd, Denmark) provided the carbonic anhydrase enzyme. The sample provenance information for the chemicals is provided in Table 1. All chemicals were used without further purification.

2.2. Measurement of Density and Viscosity. The amino acid and potassium hydroxide were weighed in the corresponding molar ratios of potassium lysinate as given by eq
2. The molecular weight of potassium lysinate is $184 \mathrm{~g} \cdot \mathrm{mol}^{-1}$. L-Lysine contributes $145 \mathrm{~g}$ in the formation of potassium lysinate, which requires $146.19 \mathrm{~g}$ of pure lysine. Accounting for the water of hydration and $1 \%$ impurity, the amount of L-lysine is $165.86 \mathrm{~g}$ of sampled L-lysine. Similarly, the $\mathrm{KOH}$ was used as supplied by the source (no drying was carried out). More information can be seen in the attached excel sheet. Moreover, no additional amount of $\mathrm{KOH}$ was added to account for the actual purity of the alkali $(84.3 \% \mathrm{KOH})$ as compared to that reported by the source $(>85 \%)$. This is due to the hygroscopic nature of potassium hydroxide. No additional amount of potassium hydroxide was added to account for the purity determined by our own analysis, conducted later. Therefore, the formed potassium L-lysinate salt has a 0.0065 mass fraction of unreacted lysine, when corrected for the potassium hydroxide purity. See the note on the $\mathrm{KOH}$ purity in the Supporting Information. 
All chemicals were weighed on a Mettler PM1200 mass balance $(u=0.1 \mathrm{mg})$. The chemicals were then dissolved in deionized water to form solutions of required concentration. The carbonic anhydrase was added later to these solutions in concentrations from 0.85 to $3.4 \mathrm{~g} \cdot \mathrm{L}^{-1}$ at $298.15 \mathrm{~K}$. The concentration values for the enzyme are also presented in units of grams of enzyme per kilogram of potassium lysinate solutions in requisite data tables, by dividing with the density of potassium lysinate solutions.

Measurements were reiterated thrice, while the samples were prepared afresh. The reference densities and viscosities of deionized water and known $\mathrm{NaCl}$ concentrations were measured to confirm the calibration of the equipment and are given in Table 2.

\section{RESULTS AND DISCUSSION}

Table 3 presents the density values for the aqueous blends of carbonic anhydrase and potassium lysinate for a range of solution concentrations and temperatures.

The values of density have an increasing linear relationship with concentration, as commonly observed with other conventional carbon capture solvents, as shown in Figure 2.

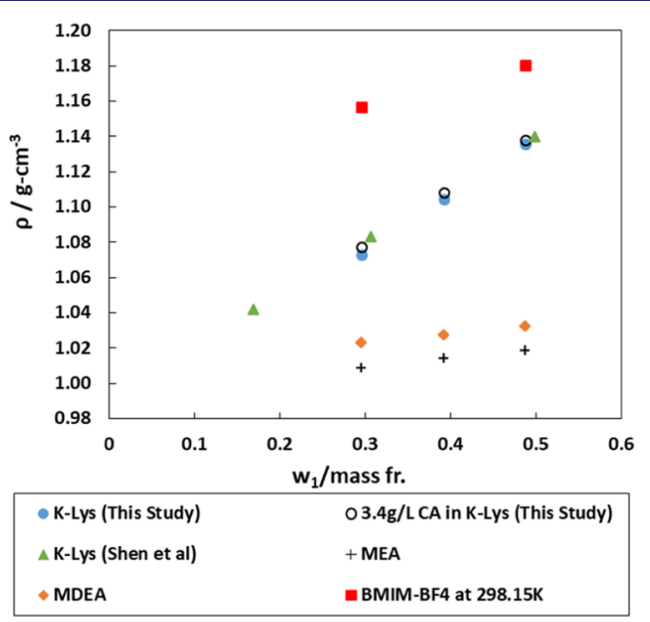

Figure 2. Effect of solvent concentration on the density for various carbon capture solvents at $303.15 \mathrm{~K}$ (except for ionic liquid, 1-butyl-3methylimidazolium tetrafluoroborate $\left(\mathrm{BMIMBF}_{4}\right)$ given at $\left.298.15 \mathrm{~K}\right)$. The potassium lysinate (K-Lys) values from the literature were taken from Shen et al. ${ }^{8}$ after conversion to mass fraction.

The density value of the potassium salt of L-lysine increases sharply with an increase in its concentration that is visible from the results of this study and Shen et al. ${ }^{8}$ We have slightly lower density values with a mean difference of $0.005 \mathrm{~g} \cdot \mathrm{cm}^{-3}$ over a range of concentrations. The difference reduces with an increase in the value of weight percent.

The same behavior is seen for MEA and MDEA but the slope of the density versus solvent concentration is not as steep as seen for our case. This may be attributed to the presence of a large number of hydroxide ions in the potassium lysinate that breaks the icelike structure of water, causing the water molecules to collapse and come closer in the liquid state. ${ }^{27}$

The density of our studied solvent is higher than those of MEA and MDEA for all concentrations but lower than ionic liquids. This can be explained by the difference in the molecular weights of the solvent molecules (which are in the order of MEA < MDEA < K-Lys < BMIMBF4).
Since the amount of enzyme in the solutions is very small, it has a very small positive effect on the overall density value. This effect is further reduced with an increase in the potassium lysinate concentration because of the presence of large potassium lysinate molecules that overwhelm the dissolution of organic molecules (like enzymes) in water. ${ }^{18}$

Figures 3-5 show the behavior of density with respect to the temperature. With an increase in temperature values, a

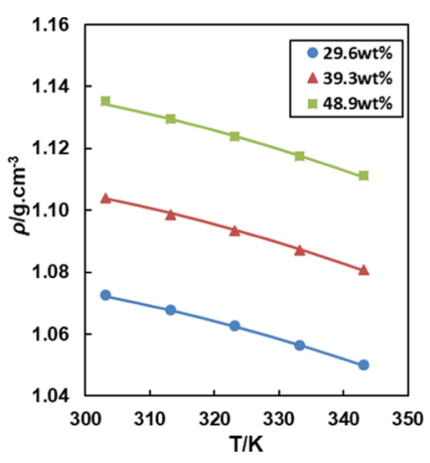

Figure 3. Density of aqueous potassium lysinate solutions with respect to temperature (no carbonic anhydrase). The dots represent the experimental values, whereas the lines represent the model's correlation.

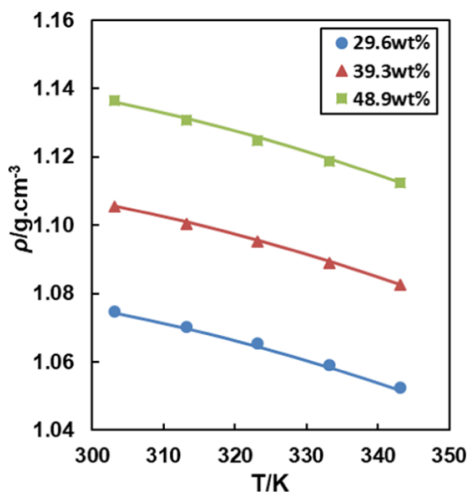

Figure 4. Density of aqueous potassium lysinate solutions blended with $1.7 \mathrm{~g} \cdot \mathrm{L}^{-1}$ carbonic anhydrase with respect to temperature. The dots represent the experimental values, whereas the lines represent the model's correlation.

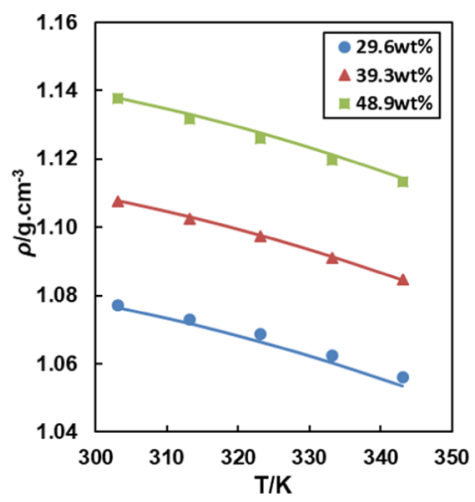

Figure 5. Density of aqueous potassium lysinate solutions blended with $3.4 \mathrm{~g} \cdot \mathrm{L}^{-1}$ carbonic anhydrase with respect to temperature. The dots represent the experimental values, whereas the lines represent the model's correlation. 
decrease in density is observed. This is common as with other carbon capture solvents. An increase in temperature causes an increase in the mean molecular energies, causing the molecules to separate farther while having the same mass, giving the observed trend. The enzyme concentration has a very small effect on the density values, as evident from Figure 6.

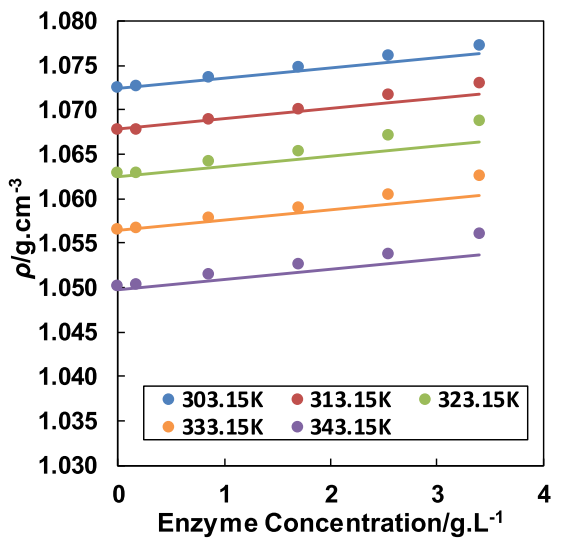

Figure 6. Density of various carbonic anhydrase concentrations blended with 29.6 wt \% aqueous potassium lysinate solutions with respect to temperature. The dots represent the experimental values, whereas the lines represent the model's correlation.

Table 4 presents the viscosity values of the aqueous blends of carbonic anhydrase and potassium salt of L-lysine for a range of solution concentrations and temperatures.

Viscosity values increase with the increase in the amino acid salt and enzyme concentration and follow the profile as commonly seen with other conventional solvents, ${ }^{28}$ as shown in Figure 7. The viscosity values of the potassium salt of $\mathrm{L}$ lysine are in good coherence with the results form Shen et al. ${ }^{8}$

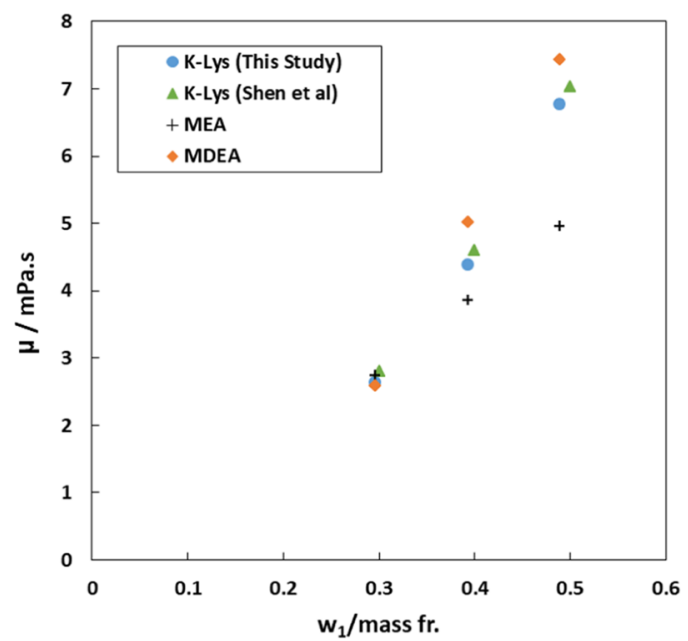

Figure 7. Effect of solvent concentration on the viscosity for various carbon capture solvents at $303.15 \mathrm{~K}$. The potassium lysinate (K-Lys) values from the literature were taken from Shen et al. ${ }^{8}$ after conversion to mass fraction.

It is interesting to note that the behavior of MEA shows that it may have lower viscosity at its higher concentrations than potassium lysinate. MDEA has a very steep increase in the viscosity with concentration, as compared to our L-lysinate solutions. This hints that at lower concentrations, L-lysinate will have almost similar viscosities to those of MDEA due to the inherent behavior of water. However, both presumptions are not experimentally tested, but the trend extrapolations of

Table 4. Experimental Values of Viscosity $(\mu)$ for [Potassium Lysinate + L-Lysine ${ }^{a}(1)+$ Water (2) as a Function of the Mass Fraction of Potassium Lysinate $\left(w_{1}\right)$ and Grams of Carbonic Anhydrase Per Kilogram of the Solution $\left(w_{3}\right)$ at Different Temperatures $(T)$ and Pressure $=101.325 \mathrm{kPa}^{b, c}$

\begin{tabular}{|c|c|c|c|c|c|c|c|}
\hline \multirow[b]{2}{*}{$w_{1}$ (mass fr.) } & $d$ & \multirow[b]{2}{*}{$w_{3}\left(\mathrm{~g} \cdot \mathrm{kg}^{-1}\right)$} & \multicolumn{5}{|c|}{$T(\mathrm{~K})$} \\
\hline & $C_{3}\left(g \cdot L^{-1}\right)^{d}$ & & $\begin{array}{c}303.15 \\
\mu(\mathrm{mPa} \cdot \mathrm{s})\end{array}$ & $\begin{array}{c}313.15 \\
\mu(\mathrm{mPa} \cdot \mathrm{s})\end{array}$ & $\begin{array}{c}323.15 \\
\mu(\mathrm{mPa} \cdot \mathrm{s})\end{array}$ & $\begin{array}{c}333.15 \\
\mu(\mathrm{mPa} \cdot \mathrm{s})\end{array}$ & $\begin{array}{c}343.15 \\
\mu(\mathrm{mPa} \cdot \mathrm{s})\end{array}$ \\
\hline \multirow[t]{6}{*}{0.296} & 0.00 & 0.000 & 2.634 & 2.002 & 1.564 & 1.250 & 1.017 \\
\hline & 0.17 & 0.158 & 2.636 & 2.004 & 1.566 & 1.252 & 1.019 \\
\hline & 0.85 & 0.791 & 2.643 & 2.010 & 1.573 & 1.258 & 1.025 \\
\hline & 1.70 & 1.580 & 2.650 & 2.018 & 1.582 & 1.266 & 1.033 \\
\hline & 2.55 & 2.367 & 2.658 & 2.026 & 1.588 & 1.273 & 1.042 \\
\hline & 3.40 & 3.153 & 2.665 & 2.034 & 1.596 & 1.282 & 1.049 \\
\hline \multirow[t]{6}{*}{0.393} & 0.00 & 0.000 & 4.384 & 3.220 & 2.447 & 1.923 & 1.536 \\
\hline & 0.17 & 0.158 & 4.386 & 3.222 & 2.449 & 1.925 & 1.538 \\
\hline & 0.85 & 0.791 & 4.393 & 3.229 & 2.455 & 1.931 & 1.544 \\
\hline & 1.70 & 1.580 & 4.401 & 3.236 & 2.463 & 1.939 & 1.552 \\
\hline & 2.55 & 2.367 & 4.408 & 3.244 & 2.471 & 1.947 & 1.561 \\
\hline & 3.40 & 3.153 & 4.416 & 3.252 & 2.478 & 1.955 & 1.568 \\
\hline \multirow[t]{6}{*}{0.489} & 0.00 & 0.000 & 6.764 & 4.831 & 3.589 & 2.749 & 2.161 \\
\hline & 0.17 & 0.158 & 6.766 & 4.833 & 3.591 & 2.751 & 2.164 \\
\hline & 0.85 & 0.791 & 6.771 & 4.839 & 3.598 & 2.757 & 2.169 \\
\hline & 1.70 & 1.580 & 6.780 & 4.846 & 3.605 & 2.765 & 2.178 \\
\hline & 2.55 & 2.367 & 6.787 & 4.854 & 3.613 & 2.773 & 2.185 \\
\hline & 3.40 & 3.153 & 6.796 & 4.863 & 3.622 & 2.781 & 2.193 \\
\hline
\end{tabular}

${ }^{a}$ Potassium lysinate formed in this study contains a 0.0065 mass fraction of unreacted L-lysine. ${ }^{b}$ Standard uncertainties are $u(T)=0.1 \mathrm{~K}, u(P)=0.3$ $\mathrm{kPa}, u\left(C_{3}\right)=0.001$ mass fraction, and $u\left(w_{1}\right)=0.001$ mass fraction. ${ }^{c}$ Expanded uncertainty is $U_{\mathrm{c}}(\mu)=0.0163 \mathrm{~g} \cdot \mathrm{cm}^{-3}\left(0.95\right.$ level of confidence). ${ }^{d} C_{3}$ is the concentration of carbonic anhydrase in $1 \mathrm{~L}$ of solution. 
our current data show that at nearly 58 wt \% concentration of potassium L-lysine, its viscosity value will be greater than that of MDEA.

Figures 8-10 show the effect of temperature on the viscosity of the studied solvent. The viscosity follows a declining

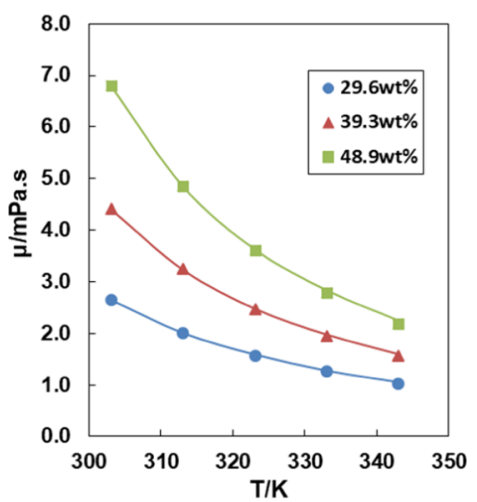

Figure 8. Viscosity of aqueous potassium lysinate solutions with respect to temperature (no carbonic anhydrase). The dots represent the experimental values, whereas the lines represent the model's correlation.

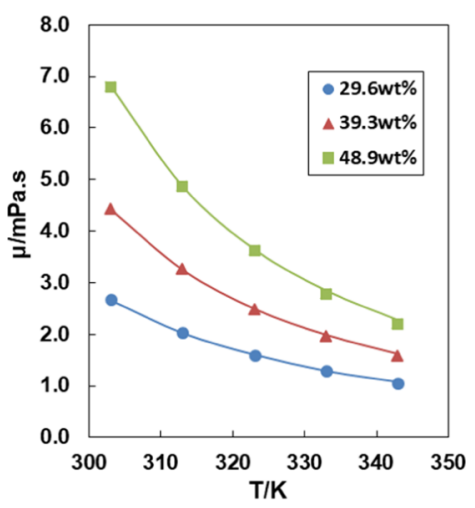

Figure 9. Viscosity of aqueous potassium lysinate solutions blended with $1.7 \mathrm{~g} \cdot \mathrm{L}^{-1}$ carbonic anhydrase with respect to temperature. The dots represent the experimental values, whereas the lines represent the model's correlation.

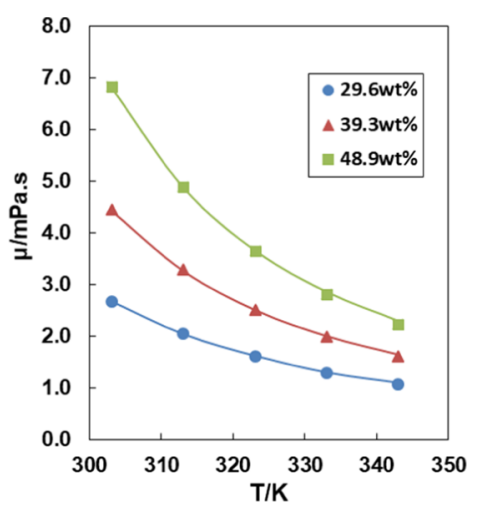

Figure 10. Viscosity of aqueous potassium lysinate solutions blended with $3.4 \mathrm{~g} \cdot \mathrm{L}^{-1}$ carbonic anhydrase with respect to temperature. The dots represent the experimental values, whereas the lines represent the model's correlation.

exponential profile as a function of temperature. This is explained by the reduction in the cohesive forces present between the layers of the liquid solvent that allows the fluid to move more easily. The enzyme concentration has a very small effect on the viscosity values, as evident from Figure 11.

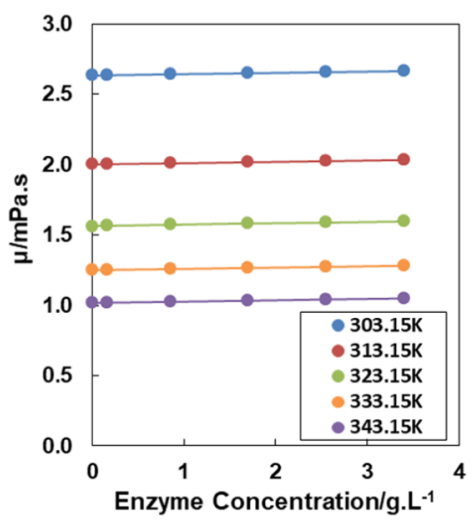

Figure 11. Viscosity of various carbonic anhydrase concentrations blended with $29.6 \mathrm{wt} \%$ aqueous potassium lysinate solutions with respect to temperature. The dots represent the experimental values, whereas the lines represent the model's correlation.

\section{CORRELATION OF PHYSICOCHEMICAL PROPERTIES}

The experimental values were correlated by two linear semiempirical equations (eqs 3 and 4) given for density and viscosity, respectively. Table 5 provides the values and units of the parameters for each equation. An average absolute relative error of $0.06 \%$ for density and $2.86 \%$ for viscosity are observed. The data table of the correlated values with individual experimental values is given in Table S1 of the Supporting Information.

$$
\begin{aligned}
& \rho=\rho_{\mathrm{H}_{2} \mathrm{O}}\left(k_{1}+k_{2} W_{\mathrm{PL}}+k_{3} W_{\mathrm{CA}}+k_{4} T\right) \\
& \mu=\mu_{\mathrm{H}_{2} \mathrm{O}}\left(k_{\mathrm{a}}+k_{\mathrm{b}} W_{\mathrm{PL}}+k_{\mathrm{c}} W_{\mathrm{CA}}+k_{\mathrm{d}} T+k_{\mathrm{e}} W_{\mathrm{PL}} T\right)
\end{aligned}
$$

where $W_{\mathrm{PL}}$ represents the concentration of potassium lysinate, $W_{\mathrm{CA}}$ is the concentration of the enzyme carbonic anhydrase, and $T$ is the temperature. Kell and Vogel equations (given in the Supporting Information) were used for calculation of the density $\left(\rho_{\mathrm{H}_{2} \mathrm{O}}\right)$ and viscosity $\left(\mu_{\mathrm{H}_{2} \mathrm{O}}\right)$ values for water. The values of regression parameters for eqs 3 and 4 are presented in Table 5.

Figures 12 and 13 present the parity plots of the correlated and experimental values of the physicochemical properties of the studied solvent. The density values are an excellent fit as they are linear in nature for all studied process parameters. The correlation of viscosity is good with a few correlated values deviating up to $4.7 \%$ at high enzyme concentration (2.55 and $\left.3.4 \mathrm{~g} \cdot \mathrm{L}^{-1}\right)$.

\section{COMPARISON OF PHYSICOCHEMICAL PROPERTIES WITH OTHER SOLVENTS FOR CARBON CAPTURE}

The measured values of density and viscosity were compared with similar data found in the open literature. Pointwise data used for comparison are provided in Table S2 of the Supporting Information.

The comparison shows that the values of density for our investigated solvent is just below the ionic liquids, as shown in 
Table 5. Values of Parameters for Use in eqs 3 and 4

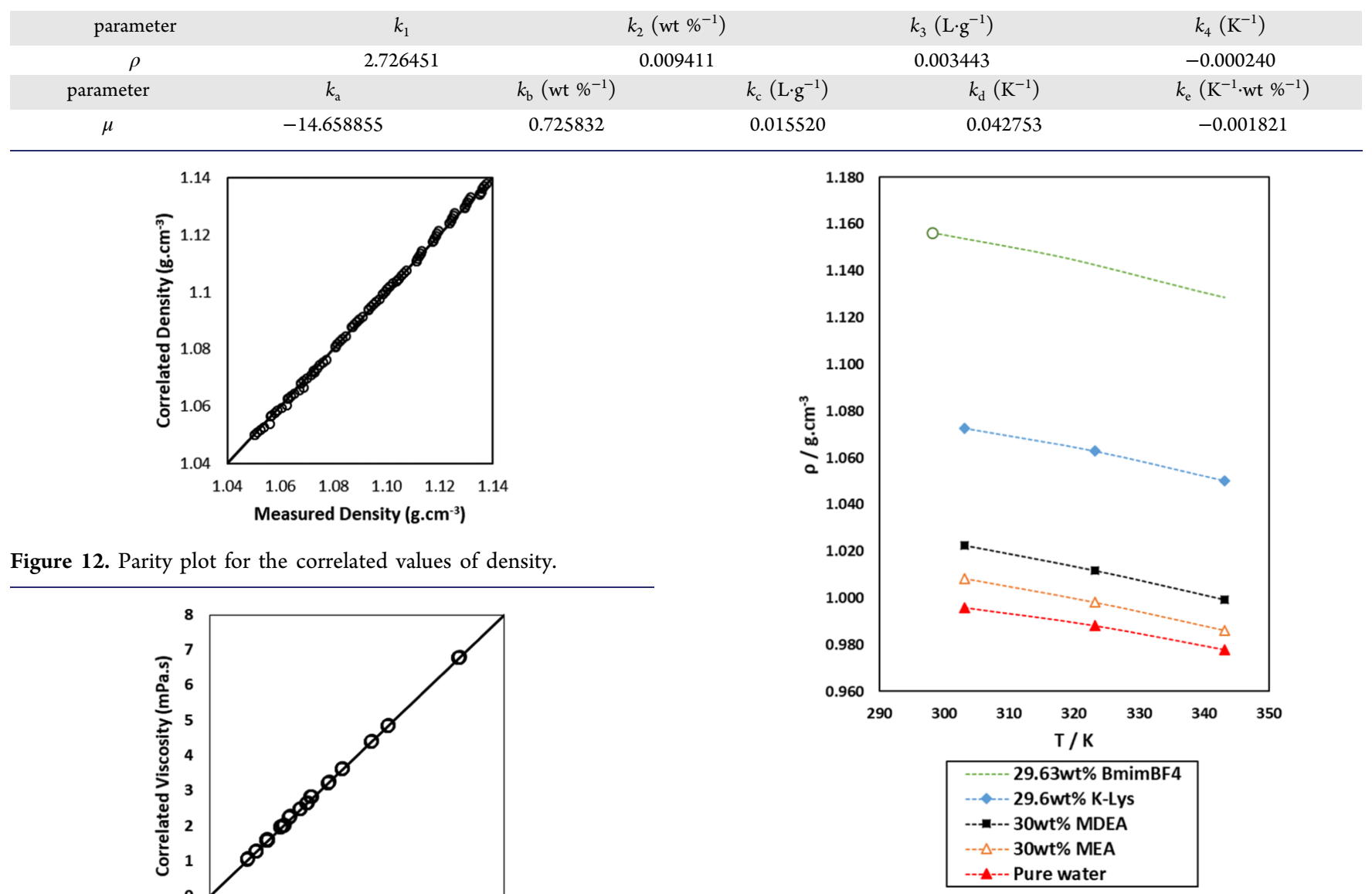

Figure 14. Comparison of the density values of the studied solvent with conventional solvents at $\sim 30$ wt $\%$ concentration. Sources of density values for other solvents are provided in Table S2 of the Supporting Information. The dotted lines represent the behavior of the density with respect to an increase in temperature.

Figure 14. This is attributed to the differences in molecular weight. The smaller the molecular weight of a solvent, the smaller is the density value. As our solvent of interest has a higher molecular weight than MEA and MDEA but lower than $\mathrm{BMIMBF}_{4}$, the density value lies accordingly for all temperatures. However, carbon capture solvents with higher molecular weights are not beneficial for carbon capture, as they require higher solvent flow rates in the column and increase the operational costs.

The increase in temperature increases the mean molecular energies of the water molecules. This expands the void spaces between the liquid water molecules, while the mass remains constant, resulting in a drop in density value with an increase in temperature.

The viscosity values of the studied solvent lie just above the MEA but are lower than the MDEA, as shown in Figure 15. The lower viscosity values for our studied solvent as compared to MDEA can be attributed to the presence of hydroxide ions that break water's icelike structures, reducing the cohesive forces between the molecules. ${ }^{27}$

An increase in the concentration of the solvent has an interesting sharp effect on the viscosity when compared to MEA and MDEA conventional solvents.

A solvent with a lower viscosity value (at the same concentration) ensures a better mass transfer rate in the absorber, which reduces the size of the column and improves

the heat transfer in the reboiler of the desorber and heat exchanger present between the absorber and the desorber. Lower values of viscosity also promise a low pumping cost around the absorber/desorber arrangement. These parameters will help in reducing the capital and operation costs and provide benefits, like the ease of operation and handling.

The use of amino acids in carbon capture is a potentially sustainable solution to climate change. The amino acids combined with small quantities of carbonic anhydrase may provide a good absorption capacity and fast reactive kinetics. ${ }^{29}$

\section{CONCLUSIONS}

New bio-friendly absorbents for carbon capture will help to reduce the environmental risks and hazards associated with the technology. We present a blend of carbonic anhydrase enzyme (found in human blood) and potassium salt of L-lysine, an amino acid as a new absorbent for carbon capture. As the initial analysis, we studied the physicochemical properties of densities and viscosities of the carbonic anhydrase and potassium lysinate for absorber conditions. It was found that the said solvent has lower viscosity than the MDEA used for carbon capture, which is beneficial for achieving better mass transfer and material flow while maintaining high absorption capacity. Both properties are correlated by a semiempirical equation with an excellent agreement, and an $\mathrm{AAD} \%$ of $0.06 \%$ 


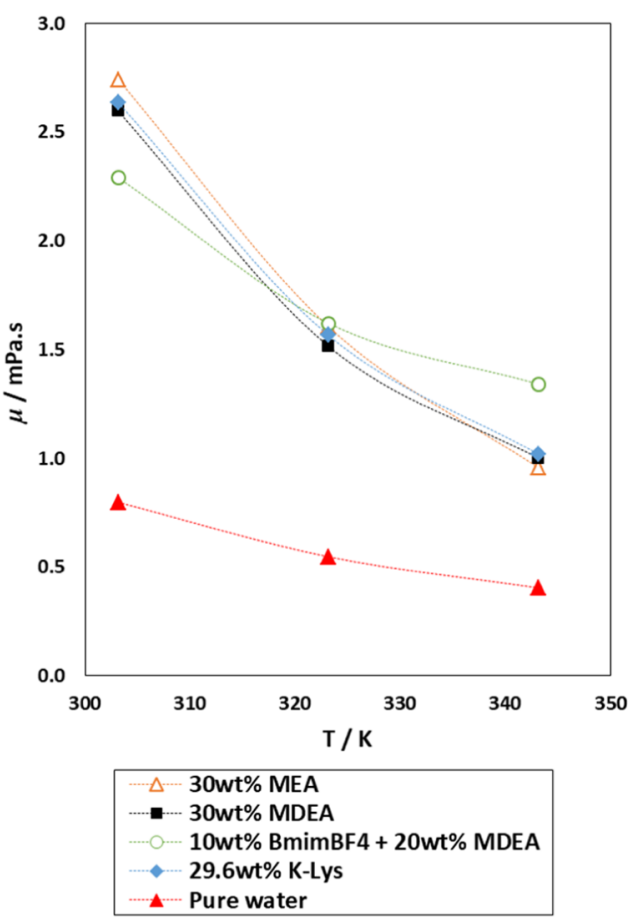

Figure 15. Comparison of the viscosity values of the studied solvent with conventional solvents at $\sim 30 \mathrm{wt} \%$ concentration. Sources of viscosity values for other solvents are provided in Table S2 of the Supporting Information. The dotted lines represent the behavior of the viscosity with respect to an increase in temperature.

for density and $2.86 \%$ for viscosity were observed. Being environmentally neutral and biomimetic, the blend can be utilized as a sustainable solvent option for carbon dioxide separation systems.

\section{ASSOCIATED CONTENT}

\section{(s) Supporting Information}

The Supporting Information is available free of charge at https://pubs.acs.org/doi/10.1021/acs.jced.9b00963.

$\mathrm{KOH}$ purity and oxidative degradation of L-lysine (Tables S1-S3) (PDF)

\section{AUTHOR INFORMATION}

\section{Corresponding Author}

Philip Loldrup Fosbøl - Center for Energy Resources Engineering, Department of Chemical and Biochemical Engineering, Technical University of Denmark, Kongens Lyngby 2800, Denmark; 다이.org/0000-0003-1067-2348; Email: plf@kt.dtu.dk

Author

Humbul Suleman - School of Computing, Engineering and Digital Technologies, Teesside University, Middlesbrough TS1 3BX, United Kingdom; 이이.org/0000-0003-1917-6471

Complete contact information is available at:

https://pubs.acs.org/10.1021/acs.jced.9b00963

\section{Notes}

The authors declare no competing financial interest.

\section{ACKNOWLEDGMENTS}

The authors would like to acknowledge the Eurotech Postdoc Programme. This project has received funding from the European Union's Horizon 2020 Research and Innovation Programme under the Marie Skłodowska-Curie grant agreement No. 754462.

\section{REFERENCES}

(1) Kohl, A. L.; Nielsen, R. B. Gas Purification; Elsevier Gulf: Houston, 1997.

(2) Shao, R.; Stangeland, A. Amines Used in $\mathrm{CO} 2$ Capture-Health and Environmental Impacts. Bellona Rep. 2009, 49, 1-49.

(3) Leung, D. Y. C.; Caramanna, G.; Maroto-Valer, M. M. An Overview of Current Status of Carbon Dioxide Capture and Storage Technologies. Renewable Sustainable Energy Rev. 2014, 39, 426-443.

(4) Eide-Haugmo, I.; Brakstad, O. G.; Hoff, K. A.; Sørheim, K. R.; da Silva, E. F.; Svendsen, H. F. Environmental Impact of Amines. Energy Procedia 2009, 1, 1297-1304.

(5) Aronu, U. E.; Svendsen, H. F.; Hoff, K. A. Investigation of Amine Amino Acid Salts for Carbon Dioxide Absorption. Int. J. Greenhouse Gas Control 2010, 4, 771-775.

(6) Lerche, B. M.; Stenby, E. H.; Thomsen, K. $\mathrm{CO}_{2}$ Capture from Flue Gas Using Amino Acid Salt Solutions; Technical University of DenmarkDanmarks Tekniske Universitet, Risø National Laboratory for Sustainable EnergyRisø Nationallaboratoriet for Bæredygtig Energi, 2012.

(7) Majchrowicz, M. E.; Brilman, D. W. F. W.; Groeneveld, M. J. Precipitation Regime for Selected Amino Acid Salts for $\mathrm{CO}_{2}$ Capture from Flue Gases. Energy Procedia 2009, 1, 979-984.

(8) Shen, S.; Yang, Y.; Wang, Y.; Ren, S.; Han, J.; Chen, A. CO2 Absorption into Aqueous Potassium Salts of Lysine and Proline: Density, Viscosity and Solubility of $\mathrm{CO}_{2}$. Fluid Phase Equilib. 2015, 399, 40-49.

(9) Shen, S.; Yang, Y.-n. Carbon Dioxide Absorption into Aqueous Potassium Salt Solutions of Arginine for Post-Combustion Capture. Energy Fuels 2016, 30, 6585-6596.

(10) Xu, G.-W.; Zhang, C.-F.; Qin, S.-J.; Gao, W.-H.; Liu, H.-B. GasLiquid Equilibrium in a $\mathrm{CO}_{2}-\mathrm{MDEA}-\mathrm{H}_{2} \mathrm{O}$ System and the Effect of Piperazine on It. Ind. Eng. Chem. Res. 1998, 37, 1473-1477.

(11) Guo, H.; Li, H.; Shen, S. $\mathrm{CO}_{2}$ Capture by Water-Lean Amino Acid Salts: Absorption Performance and Mechanism. Energy Fuels 2018, 32, 6943-6954.

(12) Shen, S.; Feng, X.; Zhao, R.; Ghosh, U. K.; Chen, A. Kinetic Study of Carbon Dioxide Absorption with Aqueous Potassium Carbonate Promoted by Arginine. Chem. Eng. J. 2013, 222, 478-487.

(13) Li, C.; Zhao, Y.; Shen, S. Aqueous Potassium Lysinate for $\mathrm{CO}_{2}$ Capture: Evaluating at Desorber Conditions. Energy Fuels 2019, 33, 10090-10098.

(14) Li, C.; Shi, X.; Shen, S. Performance Evaluation of Newly Developed Absorbents for Solvent-Based Carbon Dioxide Capture. Energy Fuels 2019, 33, 9032-9039.

(15) Zhao, Y.; Bian, Y.; Li, H.; Guo, H.; Shen, S.; Han, J.; Guo, D. A Comparative Study of Aqueous Potassium Lysinate and Aqueous Monoethanolamine for Postcombustion $\mathrm{CO}_{2}$ Capture. Energy Fuels 2017, 31, 14033-14044.

(16) Mazinani, S.; Ramazani, R.; Samsami, A.; Jahanmiri, A.; Van der Bruggen, B.; Darvishmanesh, S. Equilibrium Solubility, Density, Viscosity and Corrosion Rate of Carbon Dioxide in Potassium Lysinate Solution. Fluid Phase Equilib. 2015, 396, 28-34.

(17) Suleman, H.; Maulud, A. S.; Man, Z. Carbon Dioxide Solubility in Aqueous Potassium Lysinate Solutions: High Pressure Data and Thermodynamic Modeling. Procedia Eng. 2016, 148, 1303-1311.

(18) Syalsabila, A.; Maulud, A. S.; Nordin, N. A. H. M.; Suleman, H. In VLE of Carbon Dioxide Loaded Aqueous Potassium Lysinate with Separate Blends of Piperazine and 2-Amino-2-Methyl-1-Propanol, AIP Conference Proceedings, 2018; p 020021.

(19) Suleman, H.; Maulud, A. S.; Syalsabila, A.; Shahid, M. Z.; Fosbøl, P. L. High-Pressure Experimental and Theoretical Study of 
$\mathrm{CO} 2$ Solubility in Aqueous Blends of Lysine Salts with Piperazine as New Absorbents. Fluid Phase Equilib. 2020, 507, No. 112429.

(20) Gladis, A.; Gundersen, M. T.; Fosbøl, P. L.; Woodley, J. M.; von Solms, N. Influence of Temperature and Solvent Concentration on the Kinetics of the Enzyme Carbonic Anhydrase in Carbon Capture Technology. Chem. Eng. J. 2017, 309, 772-786.

(21) Gladis, A.; Gundersen, M. T.; Neerup, R.; Fosbøl, P. L.; Woodley, J. M.; von Solms, N. $\mathrm{CO}_{2}$ Mass Transfer Model for Carbonic Anhydrase-Enhanced Aqueous MDEA Solutions. Chem. Eng. J. 2018, 335, 197-208.

(22) Gladis, A.; Lomholdt, N. F.; Fosbøl, P. L.; Woodley, J. M.; von Solms, N. Pilot Scale Absorption Experiments with Carbonic Anhydrase-Enhanced MDEA- Benchmarking with 30 Wt\% MEA. Int. J. Greenhouse Gas Control 2019, 82, 69-85.

(23) Jones, F. E.; Harris, G. L. ITS-90 Density of Water Formulation for Volumetric Standards Calibration. J. Res. Natl. Inst. Stand. Technol. 1992, 97, 335.

(24) Huber, M. L.; Perkins, R. A.; Laesecke, A.; Friend, D. G.; Sengers, J. V.; Assael, M. J.; Metaxa, I. N.; Vogel, E.; Mareš, R.; Miyagawa, K. New International Formulation for the Viscosity of $\mathrm{H}_{2}$ O. J. Phys. Chem. Ref. Data 2009, 38, 101-125.

(25) Arps, J. J. The Effect of Temperature on the Density and Electrical Resistivity of Sodium Chloride Solutions. J. Pet. Technol. 1953, 5, 17-20.

(26) Carvalho, G. R.; Chenlo, F.; Moreira, R.; Telis-Romero, J. Physicothermal Properties of Aqueous Sodium Chloride Solutions. J. Food Process Eng. 2015, 38, 234-242.

(27) Maham, Y.; Teng, T. T.; Hepler, L. G.; Mather, A. E. Densities, Excess Molar Volumes, and Partial Molar Volumes for Binary Mixtures of Water with Monoethanolamine, Diethanolamine, and Triethanolamine from 25 to $80{ }^{\circ} \mathrm{C}$. J. Solution Chem. 1994, 23, 195205.

(28) Aronu, U. E.; Svendsen, H. F.; Hoff, K. A.; Juliussen, O. Solvent Selection for Carbon Dioxide Absorption. Energy Procedia 2009, 1, 1051-1057.

(29) Gladis, A.; Gundersen, M. T.; Thomsen, K.; Fosbøl, P. L.; Woodley, J. M.; von Solms, N. Comparison of the Kinetic Promoter Piperazine and Carbonic Anhydrase for $\mathrm{CO}_{2}$ Absorption. Energy Procedia 2017, 114, 719-725. 